UDK 316.644-057.87:376.1-056.24(497.11)

Originalni naučni rad

\title{
SOCIAL DISTANCE STUDENTS' ATTITUDES TOWARDS DISABLED PEERS ${ }^{1}$
}

\author{
Spela Golubovic * \\ Faculty of Medicine, University of Novi Sad \\ Srdjan Milasinovic ${ }^{* *}$ \\ Academy of Criminalistic and Police Studies, Belgrade \\ Nina Brkic Jovanovic *** \\ Faculty of Medicine, University of Novi Sad
}

\begin{abstract}
Summary
Background: With the development of the society and social care, scientific and technical progress, the attitude towards the people with disabilities has changed. According to the Quebec classification of disability it represents a process created together with risk factors, children's personality, life habits and environmental factors that match child's age, gender and socio-cultural identity. The attitude represents a tendency to react positively or negatively towards certain objects, features or situations. Attitude, as a model of behaviour not firmly and definitely determined, can be formed, but also changed, mainly based on experience and interpersonal relationship as well as ones knowledge and feelings.

Aim: The main goal of this research is to determine the adolescents' attitude towards peers with disabilities.

Method: The research was conducted on 132 high school students, out of which there were 64 students in one group and a peer with a form of disability among them. The other group had 68 students, where none of them had a disability. For the needs of this research, a questionnaire has been created in order to determine the attitudes of students towards disabilities.
\end{abstract}

1 This paper was written within the scientific research project Safety and Protection of Organizing and Functioning of Educational System in the Republic of Serbia (Basic Principles, Protocols, Procedures and Resources) (No. 47017), implemented by the Faculty of Security, University of Belgrade, funded by the Ministry of Education, Science and Technological Development of the Republic of Serbia.

* Full Professor, spela@uns.ac.rs

** Full Professor, srdjan.milasinovic@kpa.edu.rs

*** Teaching Assistant, nina_brkic_85@yahoo.com 
The questionnaire consists of 20 questions where the participant can circle only one of the following options: yes, no or I do not know. The questions can be divided into 3 components - the first one regarding the cognitive component of the attitude, the second one regarding the emotional component and the third one regarding the behavioural component.

Results: Belonging to a certain group determines formatting and expressing one's opinion. Both groups of participants gave the same answers in terms that both groups believed that they were insufficiently informed about the people with disabilities. Those questions tackled the knowledge of different types of disabilities, source of information, and care for the disabled. Further results indicate that contact with the people with disabilities determines the development of a positive attitude towards them. The biggest social distance has been expressed during the analysis of emotional components of attitude, included in the questions regarding interpersonal relationship. It seems that spending time and having experience with the disabled does not significantly affect the preparation of adolescents in creating close emotional contact.

Conclusion: We emphasize that there is still heavy prejudice which makes the full integration and socialization of the people with disabilities harder. It is commonly accepted that all people learn and that their full inclusion represents the ultimate goal. However, this requires a change in the attitude of the wider social community. The final goal is determined not just by one's capabilities but also by the possibility for all other relevant factors to conform to the needs of an individual. So, going from the main idea of inclusion, that all individuals are different, the society should change and adjust so that they could meet the needs of all individuals.

Keywords: social distance, peers, disability, attitudes

\section{Introduction}

Man, as a social being, has a pronounced tendency and need of being socially accepted. The origins of social behaviour are related to the life within the family where the child acquires the first social experience. At the age of 4-5, the child begins to acquire experience within the peer group. At this age, children groups are formed with the relations of attractions, rejection, indifference, etc. The first moral performances, habits, respect for others, the pursuit of truth and the proper relationship to others are also acquired.

The ability and the willingness of a child to socialize and to have personal experience in a peer group is one of the necessary preconditions of sociability. At the same time, the child develops an opinion about itself based on the contact with other people. Depending on the number and quality of interactions, the child will build self-image and the image about the environment, which will be reflected in its quality of life and its behaviour. When we talk about both people and children with disabilities, we must bear in mind that the number of interactions with the members of the community in which they reside is often poor.

[48] NBP • Žurnal za kriminalistiku i pravo 
Disability is a term that has several definitions. Most often it is pointed out that it a condition that arises from the loss or reduction of ability to perform the expected or specially defined activities of social roles in a longer period of time, due to the chronic disease or injury. ${ }^{5} \mathrm{~A}$ wider term includes bio-psycho-social definition of disability defined in the Quebec Classification, which says: "disability is a process created in synergy of risk factors, personal traits of a child, environmental factors and lifestyle habits that match child's age, gender and socio-cultural identity". ${ }^{6}$

Caring about the disabled persons in our community dates back to the Middle Ages. Handicapped persons were selected from their primary group, and housed away from others mostly in monasteries where they were taken care about. The attitude towards them changed from neglecting and even murdering to full acceptance. With the development of society, social care systems, advancements in science and technology these attitudes towards disabled persons is being changed.

To date, even in the developed countries, people with disabilities are marginalized. Regardless of the laws that define the rights of persons with disabilities, the social consciousness is still judging the position of these people. These people are in our culture often perceived as different. Due to this attitude of community, these people usually assume themselves as different from others.

A person, who has a motor, intellectual or sensory impairment or a child with disabilities other than a direct consequence of the injury, also shows the secondary consequences - social, related to the consequences of the reactions of others to its impairment. The relationship between every person and social environment is very important. For persons with disabilities, this relationship is even more important since their disability requires this relation with others, and, on the other hand, disabled persons are exposed to a special attitude and treatment by others. Deeply rooted prejudices constitute an aggravating circumstance and an obstacle to the full socialization of the full integration of people with disabilities. Acceptance of children with disabilities from their peers is ranging from rejection, ridicule and expression of aggression to the full acceptance of children with disabilities as equal members of society. According to Hrnjica, ${ }^{7}$ the children with very hyperactive behaviour are largely unpopular so that when becoming aggressive, results in rejection by the peers.

In recent decades, there is interest in attitudes towards people with disabilities. "Attitudes are acquired disposition, willingness to a certain way of observation, thinking, emotional reaction and acting. The type of reaction depends on the experience of individuals formed during their social life." ${ }^{8}$ While all positions are characterized by relative permanence, there is a general tendency of people to try to adapt to the changes, and to change their attitudes. The attitude is a tendency to respond positively or negatively to certain features, objects or situations. ${ }^{9}$ More complex and complete definition is ${ }^{10}$

\footnotetext{
$5 \quad$ According to the World Health Organization. (1992): ICD-10 Classification of the mental and behavioral disorders. Belgrade: Zavod za udžbenike i nastavna sredstva.

6 According to the Ministry of Social Affairs of the Republic of Serbia in 1999, the Quebec Classification "The Disability Creation Process"

7 S. Hrnjica; Inkluzija kao pedagoški izazov, The Study of Ministry of Education and Sport, UNICEF and Save the Children UK, Beograd, 2009.

8 N. Rot; Osnovi socijalne psihologije, Belgrade, 2006.

9 Morgan, 1956, quoted in: N. Rot, Osnovi socijalne psihologije, Belgrade, 2006.

10 Allpert, 1956, quoted in: N. Rot, Osnovi socijalne psihologije, Belgrade, 2006.
} 
that attitude is defined as neural and mental readiness, formed based on the experience, making the directive or dynamic influence on the response of individuals to objects and situations with which it comes into contact. This definition suggests that once formed an attitude becomes relatively stable and unchanged over time.

Functional approach of the attitudes analysis deals with the issue of all functions that attitudes have or may have for the individual (instrumental, defence, function manifestation of personal values or function of learning and thinking). Another approach is structured to deal with the problem of complexity and structure of the attitude, i.e. the question of what the attitude is. According to the structural approach the three components of attitudes are defined: cognitive, affective (emotional) and conative (action) component ${ }^{11}$

Cognitive component consists of perceptions, beliefs and stereotypes of individuals in relation to a phenomenon. The affective component is determined by the feelings of an individual about the object, and the conative component consists of a tendency to react in a certain manner to a certain phenomenon. ${ }^{12}$ These three dimensions of attitudes are very rarely balanced. The correlation between the attitudes and behaviour is one of the key assumptions of the structural approach.

The attitudes based on direct experience with the object attitude are to a greater extent a predictor of behaviour than attitudes not based on experience. ${ }^{13}$ Behaviour does not always have to be a reflection of the attitude. People tend to align their behaviour with the behaviour of other people, although it may not be in compliance with their "right" attitude.

According to various criteria attitudes can be divided into: personal (typical only for certain individuals) and social (common to a number of people, related to socially significant phenomenon). Social attitudes allow efficient explanation of the behaviour of people. ${ }^{14}$ Through the assessment of attitudes we can easily and quickly determine what kind of relationship an individual has towards all kinds of things and phenomena.

Nišvić ${ }^{15}$ points out that attitudes influence our behaviour, and that, opposed to inclusion, the concept of social distance, which refers to the person's self-assessment or (un) willingness to start the interaction and activity with the person being examined. Social distance can be low, and then points to the admissibility of a population, or higher, when talking about the tendency to discriminate against certain groups.

In the most comprehensive survey of the Ministry of Education and Sports of the Republic of Serbia ${ }^{16}$ the following information regarding the relationship of children without disabilities to their peers with special needs are obtained. Interviews conducted with department peers without disabilities, show that there is a certain restraint and

11 T. L. H. Huskinson; G. Haddock; Individual differences in attitudestructure and the accessibility of the affective and cognitive components of attitude, Social Cognition, 2006, 24 (4), 453-468.

12 Mavrin-Cavor, 1981, quoted in: M. Vukajlović; Inkluzivno obrazovanje-stavovi roditelja $i$ nastavnikaprema inkluzivnom obrazovanju, Banja Luka, 2004.

13 R. H. Fazio; M. P. Zanna; On the predictive validity of attitudes: The roles of direct experience and confidence, Journal of Personality, 1981, 46 (2), 228-243.

14 N. Rot; Osnovi socijalne psihologije, Belgrade, 2006.

15 S. Nišević; N. Brkić; S. Golubović; Socijalna distanca i stavovi studenata prema osobama sa invaliditetom, Pedagogija, 2011, vol 1, 126-134.

16 According to UNICEF and Save the Children UK, 2003 Save the Children UK, Unicef (2003): Deca sa razvojnim teškoćamau redovnim osnovnim školama u Srbiji, the Ministry of Education and Sports of the Republic of Serbia.

[50] NBP • Žurnal za kriminalistiku i pravo 
selective willingness to accept their peers with disabilities. Hyperactive, aggressive and impulsive children are usually rejected by students and teachers. The dependence of the opinion of children without disabilities and their teachers about children with special needs is also observed.

Kovačevic ${ }^{17}$ reports that $48.60 \%$ of students with disabilities have difficulty in establishing contacts with peers not having these disabilities; $30.70 \%$ of children without disabilities expressed negative attitudes in the form of teasing and ridicule and $20.70 \%$ of the disabled children exhibit aggressive behaviour. Jablan et al. ${ }^{18}$ suggest that students have a major problem when it comes to customization and integration into the school environment. Their research has shown that students with visual impairments have no problem in communicating with their peers with normal sight. Specifically, $81.4 \%$ of children with visual impairment claim to have companions having normal sight, but only $23.3 \%$ of them expressed full satisfaction with the number of friends without this disability. The majority $(46.5 \%)$ is partially satisfied with the number of friends without disability, while $30.2 \%$ of pupils with visual impairments are not satisfied with the number of friends in school not having this impairment.

\section{The Aim of the Study}

The main objective of this research is to investigate what the attitudes of adolescents are towards the peers with disabilities.

\section{Methods}

The study involved a total of 132 high school pupils, of which Group A consists of 64 pupils having at least one peer who has some form of disability within the class, while group $B$ consists of 68 pupils, having no peers with disabilities within the class.

For the purposes of this study, a questionnaire to assess pupils' attitudes in relation to disability is composed. The questionnaire consisted of 20 questions which respondents completed by only one of the answers: yes, no, or I do not know. Questions can be divided into three parts. The first part related to the cognitive component of attitude and included the questions on the knowledge of the types of disability and the care of the handicapped persons. Conative component of attitude, which would correspond to social distance since it represents the behaviour of certain groups members, is questioned through the attitude towards a handicapped person as a boyfriend/girlfriend, best friend (emotional component) and through the respondents' answers to assisting the handicapped people, by sharing school table, or staying in school, etc. (behavioural component).

The survey was anonymous and voluntary, and respondents signed the consent to participate in research.

17 J. Kovačević; I. Radovanović; Pripremljenost nastavnika redovnih škola za inkluzivno obrazovanje, Beogradska defektološka škola, Belgrade, 2006, no.3, p. 125-136,.

18 B. Jablan; Z. Jolić; A. Grbović; Mišljenje srednjoškolaca sa oštećenjem vida o obrazovanju u redovnoj školi, Belgrade: Proceedings: Istraživanja u specijalnoj edukaciji i rehabilitaciji, 2009, p.589-605. 


\section{Results and Discussion}

Membership in a particular group influences the formation and reflection of the attitudes of individuals. The group chooses information that will reach its members, then emphasizes certain values and supports the maintenance of attitudes according to the group perception. The appropriate information about their capabilities, skills and characteristics allows non-disabled adolescents to form their own opinion, and thus more appropriate attitude towards them.

Both interviewed groups when questioned about the types of disability, the sources of information, or care for the disabled persons gave the same answers in the sense that both groups believed that they had lack of information about the people with disabilities. $60.93 \%$ of respondents of group A and $69.12 \%$ of those from group B consider that they are partially informed, while $32.82 \%$ of group A and $25.00 \%$ of group B consider themselves uninformed. Our respondents' opinion is formed mostly on the basis of information obtained through broadcasting, $51.56 \%$ in group A, and $63.25 \%$ in group B.

The question: Is the society sufficiently engaged in the care of the persons with disabilities, $80 \%$ in both groups of respondents declare that it is not, which could be interpreted by the fact that the obtained data probably reflect the views of the general population (Table 1).

Table 1 - Is the society sufficiently engaged?

\begin{tabular}{|l|l|l|l|l|l|l|l|l|}
\hline Respondents & Yes & $\%$ & No & $\%$ & $\begin{array}{l}\text { Without } \\
\text { answer }\end{array}$ & $\%$ & Total & $\%$ \\
\hline $\mathrm{A}(64)$ & 10 & 15.63 & 54 & 84.37 & 0 & 0 & 64 & 100 \\
\hline $\mathrm{B}(68)$ & 7 & 10.29 & 60 & 88.24 & 1 & 1.47 & 68 & 100 \\
\hline Total & 17 & 12.88 & 104 & 78.79 & 1 & 0.76 & 132 & 100 \\
\hline
\end{tabular}

In a further study there are social distance and taking into account the importance of belonging to a particular group, the information and knowledge about objects and situations to which an attitude exists. The attitudes as not quite solid and definitely determined forms of behaviour can be established, and modified, primarily on the basis of experience and mutual relationships with other people but also on the basis of knowledge and relations of the involved persons. Thus, as for the questions related to assisting the handicapped persons, sharing school table, staying in school, etc. a positive trend is evident. $64.06 \%$ of respondents in group A and $51.47 \%$ of those in group $B$ believe that the people with disabilities do not need to act within the closed society ${ }^{*}$ (of those similar to each other), while when questioned whether they should attend a special school respondents of group B in almost the same percentage answered "yes" (42.64\%) and "no" (41.18\%), while 53.13\% of respondents in group A answered "no" and $14.06 \%$ answered "yes" which contributes to the good acceptance of the peers with disabilities in this group. The respondents of both groups in over $90 \%$ of cases would offer help to a disabled person if needed. 
The results of this part of the survey confirmed our initial hypothesis that contact with the people with disabilities affects the building of a positive attitude towards them. The experience, socialization and readiness of a child to socialize with the peers who have developmental problems and gains personal experience in a peer group is a prerequisite for sociability, and acceptance in the peer group influences the building of positive attitudes towards them and overthrowing of the prejudices. The adolescents with disabilities are well accepted within their class, facing understanding and support from their peers, which is to a lesser extent identified in the attitudes of the children from the classes having no children with disabilities.

According to Nišević, ${ }^{19}$ Corrigan et al. got the similar data when concluded that the attitudes that characterize the prejudices, lead to social distance, which can be a basis for avoiding these people, as well as for discrimination and negative behaviour towards the people with mental illness. In her research a significant correlation between the scale of social distance and scale of attitudes toward the persons with physical disabilities was discovered. The greatest correlation was given between the results on the scale of attitudes towards the people with physical disabilities and the results on a scale of social distance towards the people with physical disabilities. From the above it can be assumed that people who have positive attitudes towards the people with disabilities show less distance towards the people with autism, multiple handicapped people, psychiatric patients, the people with physical disabilities and mentally retarded persons.

The greatest social distance was expressed when analyzing the emotional component of an attitude given in the analysis, the issues related to the relation between the members of certain groups. The most common socially acceptable answers ("I do not know") are given. It seems that socialization and experience with the people with disabilities do not significantly affect the willingness of adolescents to achieve a close emotional contact with them. Peers are willing to short-term relationships with emotional investment-type association at school, sharing school table, but are not ready for establishing deeper connections and greater emotional investment such as hanging out together, best friend, or boyfriend/girlfriend.

\section{Conclusion}

We conclude that there are still enrooted prejudices that hinder full socialization and integration of the people with disabilities. The process of inclusion, according to the results of this study, reveals insufficient informative and emotional component acts, whereas the adolescents only adopted a behavioural component of socially desirable behaviour towards the peers with disabilities. In order to achieve the process of inclusion in its entire concept, it is necessary to design and implement interventions acting on emotional and cognitive aspects, because only then a change in behaviour towards the people with disabilities can be long-lasting. This is of great importance for the persons with disabilities both for their emotional and social development, and for society in general.

19 S. Nišević; N. Brkić; Š. Golubović; Socijalna distanca i stavovi studenata prema osobama sa invaliditetom, Pedagogija, 2011, vol 1, 126-134. 


\section{References}

1. Allpert, 1956, quoted in: Rot, N; Osnovi socijalne psihologije, Zavod za udžbenike i nastavna sredstva, Belgrade, 2006.

2. Hrnjica, S.; Inkluzija kao pedagoški izazov. The Study of Ministry of Education and Sport, UNICEF and Save the Children UK, Beograd, 2009.

3. Huskinson, T. L. H; Haddock G; Individual differences in attitudestructure and the accessibility of the affective and cognitive components of attitude, Social Cognition, 2006, vol 24 (4), 453-468.

4. Jablan, B; Jolić, Z; Grbović, A; Mišljenje srednjoškolaca sa oštećenjem vida o obrazovanju u redovnoj školi, Belgrade: Proceedings: Istraživanja u specijalnoj edukaciji $i$ rehabilitaciji, 2009, p.589-605.

5. Kovačević, J; Radovanović, I; Pripremljenost nastavnika redovnih škola za inkluzivno obrazovanje, Beograd, Beogradska defektološka škola, 2006, no. 3, p. 125-136.

6. Mavrin-Cavor, 1981, Vukajlović, M; Inkluzivno obrazovanje-stavovi roditelja i nastavnikaprema inkluzivnom obrazovanju, Naučna knjiga/Grafid, Banja Luka, 2004.

7. Morgan, 1956, quoted in: Rot, N; Osnovi socijalne psihologije, Zavod za udžbenike i nastavna sredstva, Belgrade, 2006.

8. Nišević,S; Brkić, N; Golubović, Š; Socijalna distanca i stavovi studenata prema osobama sa invaliditetom, Pedagogija, 2011, vol 1, 126-134.

9. Rot, N; Osnovi socijalne psihologije, Zavod za udžbenike i nastavna sredstva, Belgrade, 2006.

10. Save the Children UK, Unicef (2003): Deca sa razvojnim teškoćamau redovnim osnovnim školama u Srbiji, Ministry of Education and Sports of the Republic of Serbia

11. The Ministry of Social Affairs of the Republic of Serbia, 1999. the Quebec Classification "The Disability Creation Process".

12. The World Health Organization. (1992): ICD-10 Klasifikacija mentalnih poremećaja i poremećaja ponašanja. Belgrade: Zavod za udžbenike i nastavna sredstva.

SOCIJALNA DISTANCA I STAVOVI UČENIKA

PREMA VRŠNJACIMA SA INVALIDITETOM

\section{Špela Golubović}

Medicinski fakultet Univerziteta u Novom Sadu

Srđan Milašinović

Kriminalističko-policijska akademija Beograd

Nina Brkić Jovanović

Medicinski fakultet Univerziteta u Novom Sadu

\section{Sažetak}

Razvojem društva, socijalnog staranja, napretkom nauke i tehnike, menjaju se i stavovi i odnos prema osobama s invaliditetom. Po Kvebek klasifikaciji, invaliditet nastaje u sadejstvu činioca rizika, ličnih svojstava deteta, sredin-

[54] NBP • Žurnal za kriminalistiku i pravo 
skih činilaca i životnih navika koje odgovaraju detetovom uzrastu, polu i socio-kulturnom identitetu. Stav predstavlja tendenciju da se pozitivno ili negativno reaguje prema odreðenim osobinama, objektima ili situacijama. Stavovi kao ne sasvim čvrsti i definitivno utvrdjeni oblici ponašanja mogu se formirati, ali i menjati, pre svega na osnovu iskustva i medjusobnog odnosa sa drugim ljudima ali i na osnovu toga šta o njima osoba zna i oseća.

Cilj: Glavni cilj ovog istraživanja je da se ispita kakvi su stavovi adolescenata prema vršnjacima sa invaliditetom.

Metode: U istraživanju je ukupno učestvovalo 132 učenika srednjih škola, od čega jednu grupu sačinjavaju 64 učenika sa kojima se u razredu nalazi bar jedan vršnjak koji ima neki vid invalidnosti, a drugu grupu sačinjavaju 68 učenika među kojima nema vršnjaka sa invaliditetom. Za potrebe ovog istraživanja, sastavljen je upitnik sa pitanjima kojima su procenjeni stavovi učenika u odnosu na invaliditet. Upitnik je sastavljen od 20 pitanja na koja ispitanici zaokružuju samo jedan od ponuđenih odgovora: da, ne, ne znam. Pitanja se mogu podeliti u tri celine. Prva koja se odnosi na kognitivnu komponentu stava, druga emocionalna komponenta i treća bihejvioralna komponenta.

Rezultati: Pripadnost određenoj grupi utiče na formiranje i odražavanje stavova pojedinaca. Obe grupe ispitanika dale su iste odgovore u kontekstu da veruju da su nedovoljno informisani o osobama s invaliditetom. Ova pitanja bavila su se poznavanjem različitih vrsta invaliditeta, izvorima informacija, i brigom o osobama s invaliditetom. Rezutati su takođe pokazali da kontakt s osobama s invaliditetom određuje razvoj pozitivnog stava prema njima. Najveća društvena distanca je bila izražena tokom analize emocionalnih komponenti stava, uključujući pitanja u vezi sa međuljudskim odnosima. Najveća socijalna distanca ispoljena je kada se analizira emocionalna komponeta stava. Čini se da druženje i iskustvo sa osobama sa invaliditetom ne utiču značajno na spremnost adolescenata za ostvarivanje bliskog emotivnog kontakta sa njima.

Zaključak: Zaključujemo da i dalje postoje duboko ukorenjene predrasude koje otežavaju potpunu socijalizciju i punopravnu integraciju osoba sa invaliditetom. Široko je prihvaćeno da svi ljudi treba da se informišu i da je njihova potpuna inkluzija krajnji cilj. Polazeći, od osnovne ideje inkluzije da se sve individue razlikuju među sobom, društvo treba nužno da se prilagođavaja i menja da bi izašlo u susret potrebama svih pojedinaca. 